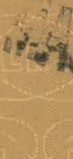 \\ Ernest 0 . Lawrence Radiation Laboratory
}

\section{PREPARATION AND STUDY OF A SERIES OF BORANE AND OCTAHYDROTRIBORATE DERIVATIVES OF METHYLATED POLYAMINES}

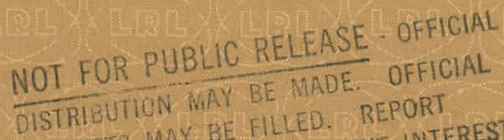 \\ REOUESTS MAY BE FILLCD. PATENT INTEREST. \\ CONTANNS NOTHTNG OF IN RECEIVING \\ PROCEDUR
SECTION. \\ Livermore, California
}




\section{DISCLAIMER}

This report was prepared as an account of work sponsored by an agency of the United States Government. Neither the United States Government nor any agency Thereof, nor any of their employees, makes any warranty, express or implied, or assumes any legal liability or responsibility for the accuracy, completeness, or usefulness of any information, apparatus, product, or process disclosed, or represents that its use would not infringe privately owned rights. Reference herein to any specific commercial product, process, or service by trade name, trademark, manufacturer, or otherwise does not necessarily constitute or imply its endorsement, recommendation, or favoring by the United States Government or any agency thereof. The views and opinions of authors expressed herein do not necessarily state or reflect those of the United States Government or any agency thereof. 


\section{DISCLAIMER}

Portions of this document may be illegible in electronic image products. Images are produced from the best available original document. 
UCRL -7948

\section{UNIVERSITY OF CALIFORNIA.}

Law rence Radiation Laboratory

Livermore, California

Contract No. W-7405-eng-48

PREPARATION AND STUDY OF A SERIES OF BORANE AND OCTAHYDROTRIBORATE DERIVATIVES OF METHY LATED POLYAMINES

F. E. Walker

R. K. Pearson

July 2, 1964

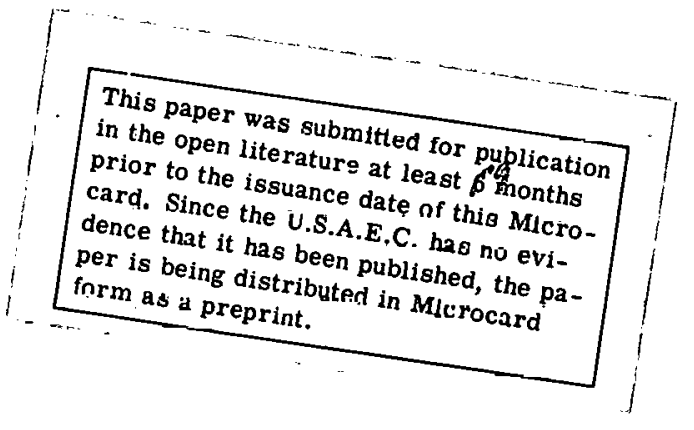


Contribution from the Lawrence Radiation Laboratory

University of California, Livermore, California

Preparation -and Study of a Series of Borane and

Octahydrotriborate Derivatives of Methylated Polyamines

By $F_{0} \cdot E$. WALKER and $R$ 。 K. PEARSON

A series of borane and octahydrotriborate derivatives

of methylated polyamines have been prepared to determine

the variance in certain chemical and physical properties

with increasing chain length of the basic amines and with

an increase in the number of carbon atoms between ad-

jacent nitrogen atoms.

Introduction

The preparation of tetramethylammonium octahydrotriborate ${ }^{-1}$ and the

(1) B. M. Graybill, J. K. Ruffo and M. F。 Hawthorne, J. A.m. Chem. Soc。 83.2669 (1961)。

diborane adduct of tetramethyl ethylenediamine ${ }^{2}$ indicated that a series of

(2) Correspondence from Callery Chemical Co.

borane and octahydrotriborate derivatives of methylated polyamines could be prepared. The facile methylation sf some sperific amines through the use of sodium: formate and formaldehyde was reported, ${ }^{3,4}$ and a study ${ }^{4,5}$ of the

(3), H. T. Clark, H. B. Gillespie, and S. Z. Weisshaus, J. Am. Chem。 Soc., 55, 457 1 (1933).

(4) A. Marxer and K. Miescher,Helv. Chim. Acta, 34, 924 (1.951).

(5) R. Rometsch, A. Marxer, and K. Miescher, ibid., 34, 1611 (1.951). 
quaternization of polyamines showed that the precursors of interest were or could be made available.

The carbon-nitrogen chains of the polyamines considered are: (a) NCCN, (b) NCCNCCN, (c) NCCNCCNCCN, and (d) NCCCNCCCN.

Representative formulae for the preparation of the amine boranes and the octahydrotriborate derivatives, respectively, follow:

$$
\begin{gathered}
\left(\mathrm{CH}_{3}\right)_{2} \mathrm{~N}\left[\left(\mathrm{CH}_{2}\right)_{2} \mathrm{NCH}_{3}\right]_{2} \mathrm{CH}_{3}+\frac{3}{2} \mathrm{~B}_{2} \mathrm{H}_{6} \\
\left(\mathrm{CH}_{3}\right)_{2} \mathrm{NBH}_{3}\left[\left(\mathrm{CH}_{2}\right)_{2} \mathrm{NCH}_{3} \mathrm{BH}_{3}\right]_{2} \mathrm{CH}_{3} \\
{\left[\left(\mathrm{CH}_{3}\right)_{3} \stackrel{+}{\mathrm{N}}\left(\mathrm{CH}_{2}\right)_{2} \stackrel{+}{\mathrm{N}}\left(\mathrm{CH}_{3}\right)_{3}\right] \cdot 2 \mathrm{I}^{-}+2 \mathrm{~KB}_{3} \mathrm{H}_{8}} \\
{\left[\left(\mathrm{CH}_{3}\right)_{3} \stackrel{+}{\mathrm{N}}\left(\mathrm{CH}_{2}\right)_{2} \stackrel{+}{\mathrm{N}}\left(\mathrm{CH}_{3}\right)_{3}\right] 2 \mathrm{~B}_{3} \mathrm{H}_{8}^{-}+2 \mathrm{KI}}
\end{gathered}
$$

\section{Experimental}

The polyamine boranes were synthesized in a vacuum line system with carefully dried reagents and solvents, and they were handled in an evacuated dry box until their qualitative air and moisture stabilities were evaluated. Adequate safety precautions were observed because of the well-known hazardous properties of diborane.

Materials. - Except in the case of ethylenediamine, where the tetramethyl diammonium diiodide was readily available, ${ }^{6}$ the methylated

(6) This material was prepared by E. R. Bissell of Lawrence Radiation Laboratory, Livermore.

polyamines and the ammonium iodides were prepared and characterized as reported. ${ }^{4,7}$ Gas chromatographic separation and purity, infrared, n. m. r.,

(7) Lawrence Radiation Laboratory, Livermore, Report UCRL-7973. 
and elemental analyses were made in addition to the b. p. determinations of the methylated polyamines considered. X-ray diffraction, infrared, and elemental analyses were made of each of the ammonium iodides to complement the m. p. data.

Preparation of Polyamine Boranes. - The following synthesis of pentamethyl diethylenetriamine tris-borane is typical for the production of polyamine boranes. A vacuum line reaction tube filled with dry argon was charged with 0.5260 g. $(3.035$ mmoles $)$ of pentamethyl diethylenetriamine. The argon was then removed; $4 \mathrm{ml}$. of dry ether was distilled into the tube, and $0.522 \mathrm{~g}$. (5.499 mmoles) of diborane was added, all while the tube was cooled in liquid nitrogen. The mixture was allowed to warm to room temperature. It was then sealed, shielded in a hood overnight, and opened on the vacuum line. A white solid extended about 3 inch up in the bottom of the tube. The ether, excess diborane, and hydrogen were removed and measured. There was 0.572 mmoles of diborane and 0.690 mmoles of hydrogen. The mole ratio of reacted diborane to amine was 1.585:1. The product was cautiously removed from the tube in a dry box. The yield of pure product was $0.644 \mathrm{~g} .(99 \%)$. After slurrying in hot water, collecting by filtration; washing with water, and drying in vacuo at $25^{\circ}$, the m. p. was $185-186^{\circ}$.

Anal. Calcd. for $\mathrm{C}_{9} \mathrm{H}_{32} \mathrm{~N}_{3} \mathrm{~B}_{3}: \mathrm{C}, 50.32 ; \mathrm{H}, 15.02 ; \mathrm{N}, 19.56$. Found: C, $50.17 ; \mathrm{H}, .14 .50 ; \mathrm{N}, 1.9 .23$.

Two diborane adducts were formed with hexamethyl triethylenetetramine. When the reaction was carried out with no solvent, the material recovered in $92 \%$ yield was the bis-borane, m. p. $118.5-119.5^{\circ}$ after recrystallization from water. The mole ratio of reactants was 1.018:1 (diborane to amine). Anal. Calcd. for $\mathrm{C}_{12} \mathrm{H}_{36}{ }^{\mathrm{N}_{4}} \mathrm{~B}_{2}: \mathrm{C}, 55.85 ; \mathrm{H}, 14.06 ; \mathrm{N}, 21.71$. Found: C, 55.11; II, $13.58 ; \mathrm{N}, 2.1 .42$. 
The second adduct, hexamethyl triethylenetetramine tetrakis -borane, was prepared in dry ether in $99 \%$ yield. The reacting mole ratio was $2.016: 1$ (diborane to amine), and the $m$. p., after slurrying. in hot water, collecting by filtration, washing, and drying in vacuo, was $208-210^{\circ}$.

Anal. Calcd. for $\mathrm{C}_{12} \mathrm{H}_{42} \mathrm{~N}_{4} \mathrm{~B}_{4}: \mathrm{C}, 50.44 ; \mathrm{H}, 14.82 ; \mathrm{N}, 19.61$. Found: C, $50.62 ; \mathrm{H}, 14.77 ; \mathrm{N}, 19.62$.

Pentamethyl di-n-propylene tris-borane was produced readily in ether. The mole ratio of diborane to amine, 1.491:1, supported the gravimetric yield data (99\%). After washing with water and drying as before, the m. p. was $185-186.5^{\circ}$ 。

Anal. Calcd. for $\mathrm{C}_{11} \mathrm{H}_{36} \mathrm{~N}_{3} \mathrm{~B}_{3}: \mathrm{C}, 54.40: \mathrm{H}_{8}, 14.94: \mathrm{N}, 17.30$. Found: C, $54.15 ; \mathrm{H}, 15.01 ; \mathrm{N}, 17.13$.

Preparation of Polyamine Octahydrotriborates. - The procedures which follow for the preparation of hexamethyl ethylenediammonium bis-octahydrotriborate and heptamethyl diethyleneaminediammonium bis-ortahydrotriborate are representative of two general methods used to synthesize the polyamine octahydrotriborates herein reported. To a 1.200-g. (3.00 mmoles) sample of hexamethyl ethylenediammonium diiodide in $50.0 \mathrm{ml}$ of isopropanol was added $0.48 \mathrm{~g} \cdot(6.0$ mmoles $)$ of potassium ortahydrnt.ribnrate. The mixture was refluxed for 30 min., the isopropanol was evaporated in vacuo to approximately one-third the original volume, and a few $\mathrm{ml}$. of water was added. Long, colorless needles formed on cooling to $0^{\circ}$. They were separated by filtration, washed with water, and dried in vacuo; yield, $0.517 \mathrm{~g}$ (76\%)。 After recrystallization from water, this material exhibited what was found to be a characteristic melting profile for the octahydrotriborate derivatives. There was a slight amber discoloration and some softening near $250^{\circ}$ and some evidence of slight decomposition, but much of the sample was still solid 
at $350^{\circ}$. This same product was obtained in a reaction with water used as a solvent as described in the following method.

Anal. Calcd. for $\mathrm{C}_{8} \mathrm{H}_{38} \mathrm{~N}_{2} \mathrm{~B}_{6}: \mathrm{C}, 42.28 ; \mathrm{H}, 16.85 ; \mathrm{N}, 12.33$. Found: C. $42.21 ; \mathrm{H}, 16.75 ; \mathrm{N}, 12.33$.

At room temperature, $2.0065 \mathrm{~g} \cdot(4.389$ mmoles): of heptamethyl diethyleneaminediammonium diiodide was dissolved in $3.0 \mathrm{ml}$. of water, and $1.0209 \mathrm{~g} \cdot(12.83 \mathrm{mmoles}$ ), of potassium octahydrotriborate was dissolved in $2.0 \mathrm{ml}$. of water. The octahydrotriborate solution was poured into the diiodide solution; and immediately a. white slurry formed. This was quickly collected by filtration, washed with.water, and dried in vacuo. The product had a weight of $1.1852 \mathrm{~g} \cdot(95 \%$ yield). Recrystallization from water gave fine, colorless needles which appeared to melt at 117-119 ${ }^{\circ}$ with an apparent change in structure and some decomposition to give a solid material that fused at $340^{\circ} \mathrm{C}$.

Anal. Calcd. for $\mathrm{C}_{11} \mathrm{H}_{45} \mathrm{~N}_{3} \mathrm{~B}_{6}: \mathrm{C}_{0} 46.46 ; \mathrm{H}, 15.95 ; \mathrm{N}, 14.78$. Found: $\mathrm{C}, 46.65 ; \mathrm{H}, 15.69 ; \mathrm{N}, 14.88$.

Octamethyl diethylenetriammonium tris-octahydrotriborate was prepared from water solutions in $81 \%$ yield.as long, narrow platelets which started fusing at $305^{\circ}$.

Anal. Calcd. for $\mathrm{C}_{12} \mathrm{H}_{56} \mathrm{~N}_{3} \mathrm{~B}_{9}$ : $\mathrm{C}, 42.40 ; \mathrm{H}, 16.61 ; \mathrm{N}, 12.36$. Found: $\mathrm{C}_{3} \cdot 42.3 .3 ; \mathrm{H}, \mathrm{]} 6.23 ; \mathrm{N}, 12.76$.

Detamethyl triethylenediaminediammonium bis-octahydrotriborate was produced in isopropanol as white prisms in $34 \%$ yield, which, after recrystallization from water, fused near $350^{\circ}$.

Anal. Calcd. for $\mathrm{C}_{14} \mathrm{H}_{52} \mathrm{~N}_{4} \mathrm{~B}_{6}: \mathrm{C}, 49.25 ; \mathrm{H}, 15.35 ; \mathrm{N}, 16.41$. Found: C, $49.67 ; \mathrm{H}, 14.87 ; \mathrm{N}, 16.10$ 。 
Decamethyl triethylenetetraammonium tetrakis-octahydrotriborate was formed from water solutions in $77 \%$ yield. Recrystallization from water gave small white prisms which started fusing at $310^{\circ}$.

Anal. Calcd. for $\mathrm{C}_{16} \mathrm{H}_{74} \mathrm{~N}_{4} \mathrm{~B}_{12}: \mathrm{N}, 12.38$. Found: $\mathrm{N}, 12.36$.

Octamethyl di-n-propylenetriammonium tris-octahydrotriborate was also prepared from water solutions, and the yield of pure material, after recrystallization from water, was $7.2 \%$. The small white prisms started fusing at $320^{\circ}$.

Anal. Calcd. for $\mathrm{C}_{14 .} \mathrm{H}_{60} \mathrm{~N}_{3} \mathrm{~B}_{9}: \mathrm{N}, 11.42$. Found: $\mathrm{N}, 11.33$.

The infrared spectra of the polyamine boranes and the octahydrotriborate salts were taken from the solids in potassium bromide wafers on a PerkinElmer Inf racord: Spectrophotometer.

\section{Table I}

Absorption Frequencies (cm. ${ }^{-1}$ ) of Boron Hydride Series ${ }^{a}$

Polyamine boranes

2860 (s)

$2310(\mathrm{vs}, \mathrm{b})$

$2040(w)$

$1460(s)$

$1160 .(s)$

$1010 .(s)$

$873(\mathrm{~m})$
Octahydrotriborates $2930(\mathrm{~m})$

$2380 \cdot(v s, b)$

$2100(\mathrm{~m})$

$1470 .(s)$

1140 (s)

$1000(s)$

953. (m)

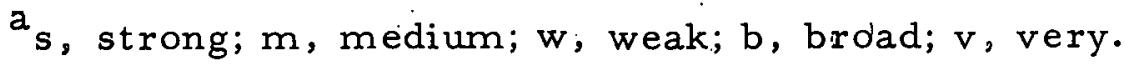

$\mathrm{X}$-ray diffraction films were made for each compound reported, and the distinguishing data is summarized. ${ }^{7}$ 
Differential thermal analyses were completed.for each compound reported herein, and the densities of pressed pellets of each were measured. These densities:are compared with the specific gravities of the parent methylated polyamines in Table II.

Table II

DTA and Density Data

\begin{tabular}{|c|c|c|c|c|}
\hline $\mathrm{BH}_{3}$ adducts & M. p. & $\mathrm{DTA}^{\mathrm{a}}$ & $\begin{array}{l}\text { S. g. } 20^{\circ} / 4 \\
\text { of amine }\end{array}$ & Density, $g_{\circ} / c c$. \\
\hline $\mathrm{C}_{6} \mathrm{H}_{22} \mathrm{~N}_{2} \mathrm{~B}_{2}^{\mathrm{b}}$ & $80^{\circ} \mathrm{C}:$ & & 0.775 & 0.91 \\
\hline $\mathrm{C}_{9} \mathrm{H}_{32}: \mathrm{N}_{3} \mathrm{~B}_{3}$ & $186^{\circ}$ & $160^{\circ}$ & 0.839 & 0.953 \\
\hline $\mathrm{C}_{12} \mathrm{H}_{42} 2^{\mathrm{N} \mathrm{N}_{4} \mathrm{~B}_{4}}$ & $210^{\circ}$ & $130^{\circ}$ & 0.861 & 0.902 \\
\hline $\mathrm{C}_{12} \mathrm{H}_{36} \mathrm{~N}_{4} \mathrm{~B}_{2}$ & $119^{\circ}$ & $108^{\circ}$ & 0.861 & 0.943 \\
\hline $\mathrm{C}_{11} \mathrm{H}_{36} \mathrm{~N}_{3} \mathrm{~B}_{3}$ & $186^{\circ}$ & $168^{\circ}$ & 0.835 & 0.895 \\
\hline $\mathrm{B}_{3} \mathrm{H}_{8}$ salts & & & . & . \\
\hline $\mathrm{C}_{8} \mathrm{H}_{38} \mathrm{~N}_{2} \mathrm{~B}_{6}$ & $>300^{\circ}$ & $125^{\circ}$ & 0.775 & 0.839 \\
\hline $\mathrm{C}_{12} \mathrm{H}_{56} \mathrm{~N}_{3} \mathrm{~B}_{9}$ & $222^{\circ}$ & $140^{\circ}$ & 0.839 & 0.853 \\
\hline $\mathrm{C}_{16} \mathrm{H}_{74} \mathrm{~N}_{4}^{\mathrm{B}} 12$ & $>300^{\circ}$ & $145^{\circ}$ & 0.861 & 0.878. \\
\hline $\mathrm{C}_{11} \mathrm{H}_{45} \mathrm{~N}_{3} \mathrm{~B}_{6}$ & $110^{\circ}$ & $115^{\circ}$ & 0.839 & 0.863 \\
\hline $\mathrm{C}_{14} \mathrm{H}_{52} \cdot \mathrm{N}_{4} \mathrm{~B}_{6}$ & $>300^{\circ}$ & $148^{\circ}$ & 0.861 & 0.862 \\
\hline $\mathrm{C}_{14} \mathrm{H}_{60} \mathrm{~N}_{3} \mathrm{~B}_{9}$ & $>3.00^{\circ}$ & $168^{\circ}$ & 0.835 & 0.859 \\
\hline
\end{tabular}




\section{Discussion}

The preparation of the precursors and the new materials described in the experimental data above is summarized in the following flow diagram:

$$
\begin{aligned}
& \mathrm{H}_{2} \mathrm{~N}\left[\left(\mathrm{CH}_{2}\right)_{a} \cdot \mathrm{NH}\right]_{b} \mathrm{H} \rightarrow\left(\mathrm{CH}_{3}\right)_{2} \mathrm{~N}\left[\left(\mathrm{CH}_{2}\right)_{a} \cdot \mathrm{NCH}_{3}\right]_{b} \mathrm{CH}_{3} \quad \text { I } a=2, b=1 . \text { III } a=2, b=3 \\
& \text { II } a=2, b=2 \text {.IV } a=3, b=2 \\
& {\left[\left(\mathrm{CH}_{3}\right)_{3} \stackrel{+}{\mathrm{N}}\left[\left(\mathrm{CH}_{2}\right)_{\mathrm{a}} \stackrel{+}{\mathrm{N}}\left(\mathrm{CH}_{3}\right)_{2}\right]_{\mathrm{b}} \mathrm{CH}_{3}\right](\mathrm{b}+1) \mathrm{x} \quad\left(\mathrm{CH}_{3}\right)_{2} \mathrm{NBH}_{3}\left[\left(\mathrm{CH}_{2}\right)_{\mathrm{a}} \mathrm{NCH}_{3} \mathrm{BH}_{3}\right]_{\mathrm{b}} \mathrm{CH}_{3}} \\
& \text { IX } \mathrm{a}=2, \mathrm{~b}=1, \mathrm{X}=\mathrm{I} \quad \mathrm{XV} \mathrm{X}=\mathrm{B}_{3} \mathrm{H}_{8}{ }^{*} \\
& \mathrm{X} a=2, b=2, \mathrm{X}=\mathrm{I} \quad \mathrm{XVI} \mathrm{X}=\mathrm{B}_{3} \mathrm{H}_{8} \\
& \text { XII } a=2, b=3, X=I \quad X V I I I \quad X=B_{3} H_{8} \\
& \text { XIV } a=3, b=2, X=I \quad X X X=B_{3} H_{8} \\
& {\left[\left(\mathrm{CH}_{3}\right)_{3} \stackrel{+}{\mathrm{N}}\left[\left(\mathrm{CH}_{2}\right)_{\mathrm{a}} \stackrel{+}{\mathrm{N}} \mathrm{CH}_{3}\right]_{\mathrm{b}}\left(\mathrm{CH}_{3}\right)_{2}\right] 2 \mathrm{x}^{-}} \\
& \text {XI } a=2, b=2, X=I \quad X V I I: X=B_{3} H_{8} \\
& \text { XIII } a=2, b=3, X=I \quad X I X . X=B_{3} H_{8}
\end{aligned}
$$

* The $\mathrm{B}_{3} \mathrm{H}_{8}$, salts have the same a and $\mathrm{b}$ values as the iodides immediately preceding them.

The methylated polyamines ${ }^{3,4}$ (I through IV) and the ammonium iodides 4,5 (IX through XIV) were prepared and characterized. ${ }^{7}$ The polyamines were obtained in $9.9 \%$ purity with gas chromatographic separation, and the iodides formed as almost colorless to bright yellow crystals, generally from ethanol. $\mathrm{X}$ and XII were produced in pressure vessels at elevated temperatures, but the others were made at.room temperature or in refluxing ethanol:

The addition of diborane to form the adducts $\mathrm{V}$ through VIII was straightforward. VII, in which only one equivalent of diborane added, was prepared with no solvent with the mole ratio of diborane added to amine greater than 3:1. The reacting mole ratio was $1.018: 1$, and the yield.was $92 \%$, indicating 
a predominantly single-product reaction, even though an excess of diborane was aviailable. It is considered, in analogy with the quaternization studies, 4,5 that both steric and electrostatic factors favor the attachment of the $\mathrm{BH}_{3}$ moiety to the terminal nitrogens. When dry ether was used as a:solvent for III, 2 moles of diborane added quantitatively giving VI.

The octahydrotriborate salts (XV through $X X$ ) were synthesized metathetically in isopropanol and in water. The reaction in water was so facile a procedure, and it provided.such good yields, that it was preferred. These octahydrotriborates could be recrystallized from water with negligible hydrolysis, when processed quickly, to give colorless to white crystalline materials.

One phase of this work was a study of the relation of chain length and chain spacing to the density and some thermal properties of the molecules synthesized. A summary of this data is given in Table II. The densities were calculated from measurements of pressed pellets, and they are, very probably, less than the theoretical values. A determination was made by. helium densitometer on $\mathrm{C}_{8} \mathrm{H}_{38} \mathrm{~N}_{2} \mathrm{~B}_{6} \cdot \mathrm{XV}$, and the value obtained was 0.86 in contrast to the pellet value of 0.839 . Some of the materials were compacted more readily than others, but, particularly with the $\mathrm{B}_{3} \mathrm{H}_{8}$ salts, density was greater with.increasing chain length, and it changed.little with the nitrogen spacing varying from two to three carbon atoms. The specific gravities of the methylated polyamines varied in this same pattern.

The temperature of the onset of the first major exotherm, as determined by differential thermal analysis, increased slightly. as the chain length of the octahydrotriborate salts increased, and the compounds with three carbon atoms between nitrogens, VIII and XX, had the highest temperature, $168^{\circ}$. Except for these correlations, the palleru was iriegular. 
The infrared absorption of the boranes near 2310 and $2040 \mathrm{~cm}^{-1}$ and the strong peaks near 2380 and $2100 \mathrm{~cm}^{-1}$ in the spectra of the octahydrotriborate salts correspond with the $\mathrm{B}-\mathrm{H}$ stretch frequencies in the $\mathrm{BH}_{3}$ and $\mathrm{B}_{3} \mathrm{H}_{8}$ moieties, respectively. There is no prominent absorption in the 2000 to $2500 \mathrm{~cm}^{-1}$ range in any of the polyamine or ammonium iodide precursors. Potassium octahydrotriborate has additional strong peaks at 1160 and 1000 $\mathrm{cm}^{-1}$, which a re alsn fnund, with some minor shifting, in tho $\mathrm{B}_{3} \mathrm{H}_{8}$ oalto. The octahydrotriborate salts, XVII and XIX, prepared from the incompletely quaternized polyamines, exhibit the characteristic octahydrotriborate absorption. However, the peaks at 2930 and $953 \mathrm{~cm}^{-1}$ appear as doublets, and more fine structure is evident, as in the analogous ammonium iodides. Acknowledgments. - We wish to acknowledge the analytical assistance. of Mrs. E. R. Smathers, Mr. J。A. Happe, and Mr. V. G. Silveira in providing elemental composition, n. m. $r_{0}$, and $x$-ray diffraction data, respectively. The work was done under the auspices of the U.S. Atomic Enèrgy Commission. 
This report was prepared as an account of. Government sponsored work. Neither the United States, nor the Commission, nor any person acting on behalf of the Commission:

A. Makes any warranty or representation, expressed or implied, with respect to the accuracy, completeness, or usefulness of the information contained in this report, or that the use of any information, apparatus, method, or process disclosed in this report may not infringe privately owned rights; or

B. Assumes any liabilities with respect to the use of, or for damages resulting from the use of any information, apparatus, method or process disclosed in this report.

As used in the above, "person acting on behalf of the Commission" includes any employee or contractor of the commission, or employee of such contractor, to the extent that such employee or contractor of the Commission, or employee of such contractor prepares, disseminates, or provides access to, any information pursuant to his employment or contract with the Commission, or his employment with such contractor. 